\title{
Formalnie słaby, nieformalnie silny. Pozycja Parlamentu Europejskiego w procedurze konsultacji na przykładzie procesu uchwalania rozporządzenia ustanawiającego zasady dobrowolnej modulacji płatności bezpośrednich
}

\begin{abstract}
Wstęp
Przeglądając literaturę poświęconą procedurom legislacyjnym w Unii Europejskiej, można dostrzec deficyt opracowań na temat konsultacji. Wydaje się to zdumiewające, biorąc pod uwagę fakt, że jeszcze do 2008 r. liczba aktów prawodawczych przyjmowanych w jej ramach była najwyższa w porównaniu do innych formuł (patrz wykres 1), przede wszystkim tak szeroko badanego współdecydowania (po Traktacie z Lizbony przemianowanego na zwykłą procedurę ustawodawcza). Wydaje się, że niewielkie zainteresowanie tym problemem wynika z powszechnie przyjętego, racjonalistycznego poglądu, iż w konsultacji rola Parlamentu sprowadza się wyłącznie do niewiążącego opiniowania Radzie projektów Komisji, toteż jest to pozycja niezmiernie słaba. Brakuje jednak empirycznych badań, które ostatecznie potwierdzałyby ten obraz.

Niniejszy artykuł jest próbą częściowego wypełnienia tej luki badawczej. Poddaje on krytyce racjonalistyczne stanowisko, proponując spojrzenie na konsultację z perspektywy konstruktywistycznej, przynoszącej zgoła odmienne wnioski. Artykuł jest ustrukturyzowany w następujący sposób. W rozdziale pierwszym charakteryzuje procedurę konsultacji. W rozdziale drugim prezentuje słabości racjonalizmu, zastępując je założeniami konstruktywizmu, na bazie których wyprowadza dwie hipotezy. W kolejnej części poddaje je weryfikacji poprzez jakościową analizę procedury uchwalania rozporządzenia ustanawiającego zasady dobrowolnej modulacji płatności bezpośrednich z 27 marca 2007 r., jednego z kluczowych aktów prawnych w dziedzinie rolnictwa. W konkluzjach podsumowuje wnioski.
\end{abstract}

\section{Charakterystyka procedury konsultacji}

Konsultacja jest jedną z najstarszych procedur legislacyjnych we Wspólnotach i w Unii Europejskiej. Została ustanowiona w Traktatach Rzymskich z 25 marca 1957 r., które przewidywały jej zastosowanie w trzydziestu trzech przepisach prawnych (dwudziestu dwóch artykułach Traktatu ustanawiającego Europejską Wspólnotę Gospodarczą oraz jedenastu Traktatu ustanawiającego Europejską Wspólnotę Energii 
Atomowej) ${ }^{1}$. Zobligowały one Radę Ministrów (EWG i Euratomu) do konsultacji ze Zgromadzeniem (EWG i Euratomu) ${ }^{2}$ określonych projektów Komisji (EWG i Eurato$\mathrm{mu}$ ) przed ich finalnym przyjęciem. Do wejścia w życie Jednolitego Aktu Europejskiego z 17/28 lutego 1986 r. $^{3}$, wprowadzającego procedurę współpracy i zgody, konsultacja była jedyną formułą legislacyjna, w której Parlament partycypował w ustalaniu wspólnotowego prawodawstwa. Kolejne traktaty rozszerzyły tę procedurę na multum nowych obszarów ${ }^{4}$, a proces ten osiagnął swój punkt kulminacyjny po przyjęciu Traktatu z Nicei z 26 lutego 2001 r. ${ }^{5}$, kiedy jej zastosowanie było przewidziane łącznie w siedemdziesięciu jeden artykułach Traktatu o Unii Europejskiej (dalej TUE) i Traktatu ustanawiającego Wspólnotę Europejską (dalej TWE) ${ }^{6}$. Traktat z Lizbony z 13 grudnia 2007 r. dokonał istotnej redefinicji procedury konsultacji. Po pierwsze, zaliczył ją do specjalnej procedury ustawodawczej, co oznacza, że jej przedmiotem mogą być tylko rozporządzenia, dyrektywy i decyzje ustawodawcze, przyjmowane przez Parlament z udziałem Rady lub przez Radę z udziałem Parlamentu (art. 289 ust. 2 i 3 TfUE) ${ }^{7}$. Po drugie, ograniczył liczbę przepisów przewidujących konsultację do pięćdziesięciu pięciu artykułów ${ }^{8}$.

Konsultacja była do niedawna procedurą, w której przyjmowano najwięcej aktów prawnych w UE (patrz wykres 1). Dominacja tej formuły była szczególnie widoczna od utworzenia Unii Europejskiej w Traktacie z Maastricht z 7 lutego 1992 r. do wejścia w życie Traktatu z Amsterdamu z 2 października 1997 r. ${ }^{9}$, kiedy uchwalano w jej ramach średnio 71,3\% całej legislacji unijnej. Tendencja spadkowa pojawiła się w 1999 r., co było efektem reform wprowadzonych przez ten ostatni akt prawny, w szczególności znacznego poszerzenia współdecydowania z piętnastu do trzydziestu jeden artykułów ${ }^{10}$, ustanowienia możliwości zakończenia tej procedury już w pierwszym czytaniu

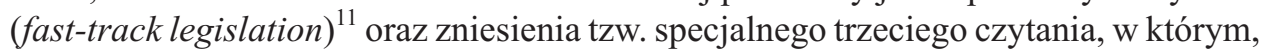

1 Traktaty Rzymskie (Traktat ustanawiajacy Europejskq Wspólnotę Gospodarcza, Traktat ustanawiajacy Europejskq Wspólnotę Energii Atomowej), Rzym, 25 marca 1957 r., http://eur-lex.europa.eu/pl/treaties/index.htm\#founding (dostęp: 20 lipca 2011 r.).

2 Traktaty Rzymskie ustanawiały jeden organ parlamentarny łączący Zgromadzenie EWG i Euratomu oraz Wspólne Zgromadzenie Europejskiej Wspólnoty Węgla i Stali. W 1958 r. przyjął on nazwę Europejskiego Zgromadzenia Parlamentarnego, a w 1962 r. Parlamentu Europejskiego. Ten ostatni termin wprowadził oficjalnie dopiero Jednolity Akt Europejski.

3 JAE wszedł w życie 1 lipca $1987 \mathrm{r}$.

4 Więcej w: A. Maurer, The Legislative Powers and Impact of the European Parliament, ,Journal of Common Market Studies" 2003, vol. 41, nr 2, s. 231.

${ }_{5}$ Traktat z Nicei wszedł w życie 1 lutego $2003 \mathrm{r}$.

6 Traktat o Unii Europejskiej i Traktat ustanawiajacy Wspólnotę Europejskq (wersja skonsolidowana), Dziennik Urzędowy UE z 29 grudnia 2006 r., C 321 E, s. 1-331.

7 Traktat o funkcjonowaniu Unii Europejskiej (wersja skonsolidowana), Dziennik Urzędowy UE z 30 marca 2010 r., C 83, s. 172.

8 A. Maurer, The European Parliament after Lisbon: Policy-making and Control, paper presented to the Federal Trust Workshop 'The European Parliament in an enlarged European Union: Beyond the Lisbon treaty', 25 April 2008, London, s. 5.

9 Traktat z Amsterdamu wszedł w życie 1 maja 1999 r.

10 R. Corbett, F. Jacobs, M. Shackleton, The European Parliament, 4th edition, London 2000, S. 191 .

11 H. Farrell, A. Héritier, Formal and informal institutions under codecision: continuous constitution building in Europe, „Governance” 2003, vol. 16, nr 4, s. 589-590; C. Reh, A. Héritier, E. Bressa- 
po fiasku koncyliacji, Rada mogła zaproponować Parlamentowi kwalifikowaną większością głosów wspólne stanowisko jako wiążące (take-it-or-leave-it) ${ }^{12}$. Mimo to, projekty konsultacyjne stanowiły większość aż do 2008 r. i dopiero wtedy ustąpiły propozycjom rozpatrywanym w ramach współdecydowania. Biorąc pod uwagę postanowienia Traktatu z Lizbony, należy przypuszczać, iż sytuacja ta powinna się utrzymać po jego wejściu w życie, a więc po 1 grudnia 2009 r.

\section{Wykres 1. Liczba projektów aktów prawodawczych zaproponowanych w ramach określonych procedur} w okresie 1993-2010

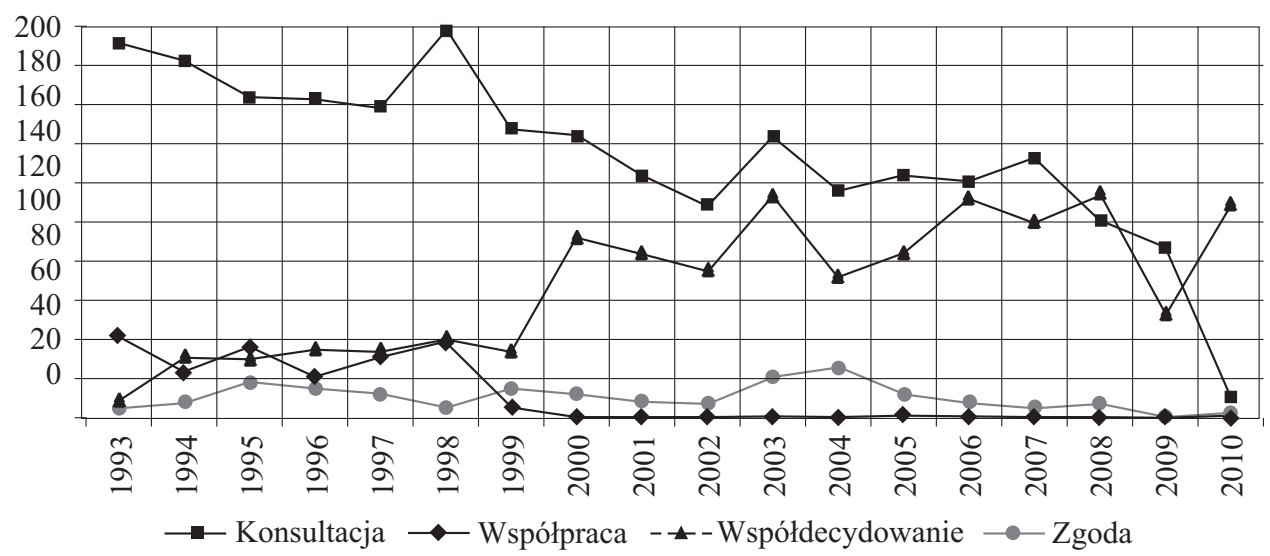

Źródło: F. Häge, The European Union Policy-Making Dataset, „European Union Politics” 2011, http://eup.sagepub.com/content/early/recent (dostęp: 12 lipca 2011 r.); Obserwatorium legislacyjne Parlamentu Europejskiego, http://www.europarl.europa.eu/oeil/index.jsp.

A contrario do współdecydowania/zwykłej procedury ustawodawczej, przebieg konsultacji nie jest zdefiniowany w żadnym artykule prawa pierwotnego. Traktaty ograniczają się wyłącznie do zawarcia w określonych przepisach obowiązku konsultacji danego projektu z Parlamentem, jednakże nie precyzują, jak należy ten termin rozumieć. W efekcie tryb tej procedury uformował się w ramach nieformalnej praktyki, przy istotnej roli orzecznictwa Trybunału Sprawiedliwości. Można go zobrazować jako sekwencję czterech etapów (patrz schemat 1). Najpierw, Komisja opracowuje projekt legislacyjny, po czym przesyła go jednocześnie do Rady i Parlamentu. Jest on poddawany pracom w tej drugiej instytucji ${ }^{13}$, a ich rezultat stanowi opinię zawierająca po-

nelli, C. Koop, The Informal Politics of Legislation: Explaining Secluded Decision-making in the European Union, paper prepared for the APSA Annual Convention, Washington, 2-5 September 2010, s. 8.

${ }^{12}$ G. Tsebelis, G. Garrett, Agenda Setting, Vetoes and the European Union's Co-Decision Procedure, „Journal of Legislative Studies” 1997, vol. 3, nr 3, s. 74-92; P. Moser, The European Parliament as a Conditional Agenda-Setter: What Are the Conditions? A critique of Tsebelis (1994), „American Political Science Review” 1996, vol. 90, nr 4, s. 834-838; G. Garrett, From the Luxemburg Compromise to Co-decision: Decision-Making in the European Union, „Electoral Studies” 1995, vol. 14, nr 3, s. 289-308.

${ }^{13}$ W rzeczywistości, projekt jest rozpatrywany także na niższych szczeblach struktury Rady, to jest w grupach roboczych, komitetach i COREPER. Jednak formalna decyzja zapada na szczeblu mi- 
prawki. Trafiają one następnie do Komisji, która może je inkorporować lub nie do projektu. Po tym etapie zmieniona lub pierwotna propozycja legislacyjna żegluje do Rady, która przyjmuje ją bez zmian kwalifikowaną większością głosów lub modyfikuje jednomyślnie. Istotą tej procedury jest fakt, że opinia Parlamentu jest niewiążąca dla Rady, dlatego ta ostatnia instytucja jest de facto jedynym i ostatecznym decydentem w procesie legislacyjnym.

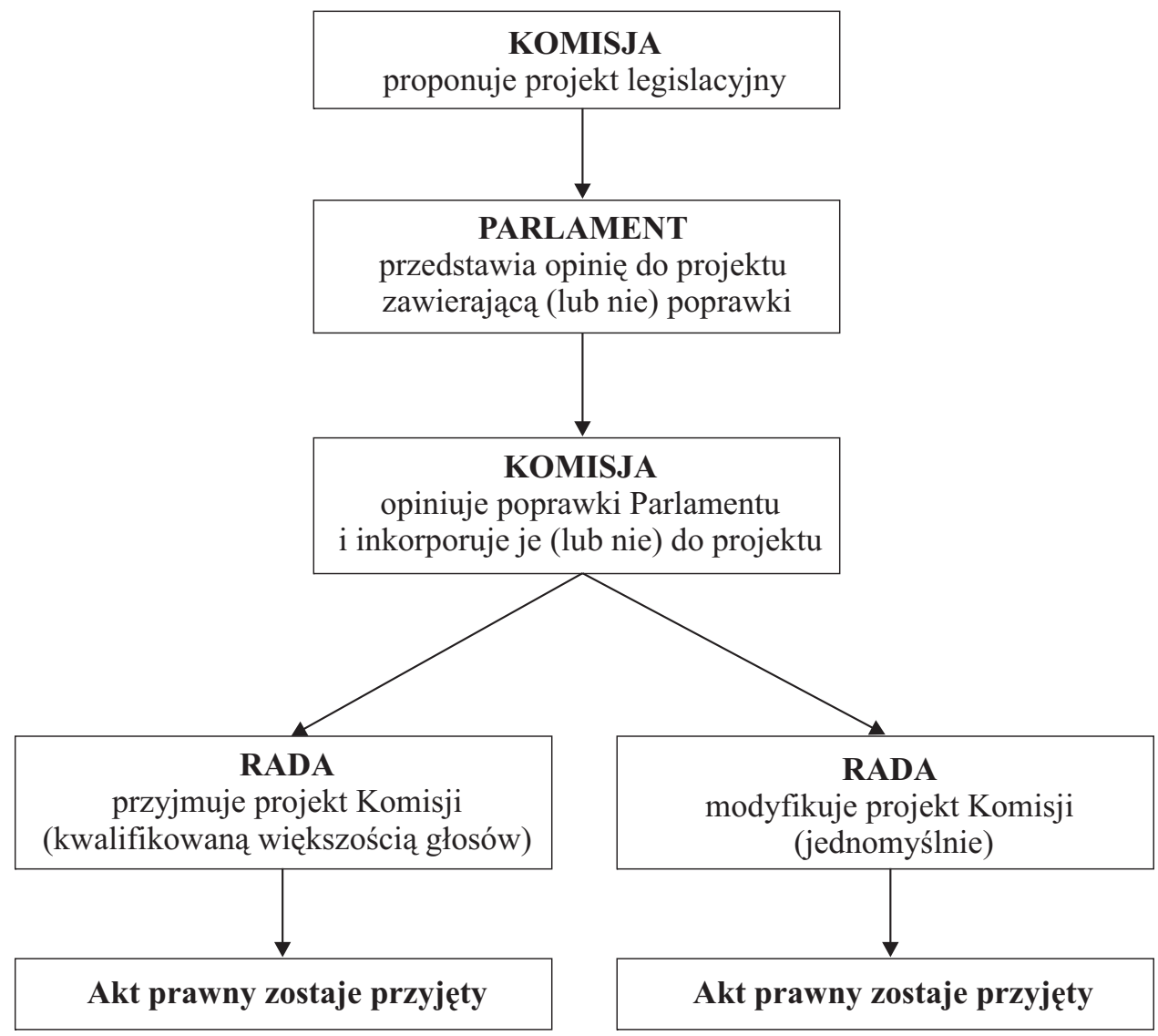

Schemat 1. Przebieg procedury konsultacji w Unii Europejskiej

Źródło: R. Corbett, F. Jacobs, M. Shackleton, op. cit., s. 177, oprac. własne.

\section{Teoria i hipotezy}

Współczesny dyskurs teoretyczny w poddziedzinie stosunków międzynarodowych, jaką są studia nad Unią Europejską, można zobrazować jako rywalizację dwóch prog-

nisterialnym dopiero po dostarczeniu opinii przez Parlament. W doktrynie przeprowadzanie takich prac przez Radę jest problematyczne. Patrz: Judgment of the Court of 10 May 1995. - European Parliament $v$ Council of the European Union, Case C-417/93, „European Court Reports” 1995, s. I-01185; S. Weatherill, P. Beaumont, EC Law, Harmondsworth 1993, s. 94. 
ramów badawczych - racjonalizmu i konstruktywizmu ${ }^{14}$. Pierwszy z nich zakłada, iż budulcem rzeczywistości są elementy materialne, takie jak zasoby naturalne, militarne, technologie czy położenie geograficzne, umniejsza natomiast znaczenie struktur ideacyjnych i normatywnych ze względu na ich niemierzalność i subiektywizm ${ }^{15}$. Taka perspektywa przejawia się w wąskim rozumieniu środowiska instytucjonalnego, składa się ono przede wszystkim z norm formalnych, które nie są autonomiczne, lecz stanowią produkt jednostek i są przez nie kontrolowane ${ }^{16}$. Ponadto, pełnią funkcję ograniczająca, nie zaś konstruująca, zachowania jednostek ${ }^{17}$.W takiej rzeczywistości poruszają się jednostki ludzkie definiowane jako istoty racjonalne (homini oeconomici), wyposażone w egzogeniczne preferencje $\mathrm{e}^{18}$. Racjonalizm ma jednak tendencję do ,grupowania" podmiotów, próbuje wyjaśniać zjawiska za pomocą takich konstrukcji redukcyjnych, jak państwo, rząd czy instytucje w sensie organizacyjnym. Jednocześnie kategorie te często postrzega unitarnie, jakby były bez wnętrza, co ma służyć wyciaganiu ogólnych wniosków oraz ograniczaniu pola badawczego do określonego pozio$\mathrm{mu}^{19}$. Tak rozumiane jednostki podejmują decyzje według logiki konsekwencji (logic of consequences), czyli kalkulują zyski i straty, kierują się maksymalizacją użyteczności, a interakcje społeczne sprowadzają do negocjacji interesów ${ }^{20}$. Przedstawioną rzeczywistość racjonaliści badają według metodologii pozytywistycznej cechującej się obiektywizmem, naturalizmem, empiryzmem i szukaniem regularności ${ }^{21}$, hołdując

14 Podział ten został zaproponowany przede wszystkim w: International Organization Exploration and Contestation in the Study of World Politics, „International Organization” 1998, vol. 52, $\mathrm{nr} 4$, special issue. Wyróżnia się jeszcze trzeci program badawczy - reflektywizm. Jednak nie nadaje się mu równoprawnego statusu z racji negacji przezeń założeń debaty naukowej. Patrz: R. Keohane, International Institutions: Two Approaches, ,International Studies Quarterly” 1988, vol. 32, nr 4, s. 379-396; M. Pollack, International Relations Theory and European Integration, „Journal of Common Market Studies” 2001, vol. 39, nr 2, s. 221-244; J. Fearon, A. Wendt, Rationalism v. Constructivism: A Skeptical View, w: Handbook of International Relations, red. W. Carlsnaes, T. Risse, B. Simmons, London 2002, s. 52-72; J. Jupille, J. Caporaso, J. Checkel, Integrating institutions: rationalism, constructivism, and the study of the European Union, „Comparative Political Studies” 2003, vol. 36, nr 1-2, s. 7-41; E. Cziomer, L. Zyblikiewicz, Zarys wspótczesnych stosunków międzynarodowych, Warszawa-Kraków 2006, s. 24; J. Czaputowicz, Teorie stosunków międzynarodowych. Krytyka i systematyzacja, Warszawa 2007, s. 295-299.

15 J. Czaputowicz, op. cit., s. 296.

16 H. Farrell, A. Heritier, A rationalist-institutionalist explanation of endogenous regional integration, „Journal of European Public Policy” 2005, vol. 12, nr 2, s. 273-290; R. Corbett, Academic modelling of the codecision procedure: A practitioner's puzzled reaction, „European Union Politics” 2000, vol. 1, nr 3, s. 373-381; idem, A response to a reply to a reaction (I hope somebody is still interested!), „European Union Politics” 2001, vol. 2, nr 3, s. 361-366.

${ }_{17}$ M. Aspinwall, G. Schneider, Institutional research on the European Union: mapping the field, $\mathrm{w}$ : The rules of integration. Institutionalist approaches to the study of Europe, red. M. Aspinwall, G. Schneider, Manchester 2001, s. 11; M. Pollack, Rational Choice and EU Policy..., s. 32.

18 J. Fearon, A. Wendt, Rationalism v. constructivism..., s. 60; M. Pollack, Rational Choice and EU Policy, w: red. K. Jørgensen, M. Pollack, B. Rosamond, The Handbook of European Union Politics, New York 2007, s. 45-46.

19 J. Checkel Social construction and integration, „Journal of European Public Policy” 1999, vol. 6, nr 4, s. 546; J. Fearon, A. Wendt, op. cit., s. 53, 65.

20 J. March, J. Olsen, The Institutional Dynamics of International Political Orders, „International Organization" 1998, vol. 52, nr 4, s. 949-951; D. Marsh, G. Stoker, Teorie i metody w naukach politycznych, Kraków 2006, s. 63-67.

21 E. Cziomer, L. Zyblikiewicz, op. cit., s. 28-29. 
jednocześnie podejściu matematyczno-ilościowym i darząc niechęcią metody jakościowe.

Biorąc pod uwagę powyższe założenia, racjonaliści stawiają tezę, iż w kontekście wszystkich procedur legislacyjnych Parlament Europejski posiada najsłabszą pozycję $w$ konsultacji ${ }^{22}$. Z perspektywy formalnoprawnej jego rola sprowadza się wyłącznie do przedstawienia opinii, które są niewiążące dla Rady. Oznacza to, że w przypadku projektów konsultacyjnych ostateczną decyzję w kwestii kształtu prawodawstwa podejmują ministrowie, a posłowie nie mają nawet nieformalnych instrumentów, aby tę sytuację zmienić ${ }^{23}$. Pozostaje im jedynie lobbowanie Komisji, aby przekształciła swój projekt zgodnie $\mathrm{z}$ ich postulatami, co generowałoby w Radzie potrzebę jednomyślności, żeby je odrzucić ${ }^{24}$. Takie warunki instytucjonalne poważnie ograniczają możliwość maksymalizacji preferencji deputowanych oraz prowadzenia negocjacji z Rada, dlatego racjonalizm postrzega konsultację jako grę pomiędzy tą ostatnią instytucją a Komisją, z której Parlament jest całkowicie wyłączony ${ }^{25}$.

Konkurencyjnym wobec racjonalizmu programem badawczym jest konstruktywizm. Jego rdzeniem jest założenie, iż rzeczywistość jest społecznie konstruowana. Ma ona charakter ambiwalentny; z jednej strony składa się z ukrytych w świadomości ludzi konstruktów ideacyjnych (społecznych), z drugiej zaś z bytów materialnych. Priorytet posiadają te pierwsze struktury, określane mianem instytucji w sensie socjologicznym, gdyż to one ożywiają i nadają znaczenie tym $\operatorname{drugim}^{26}$. Konstruktywizm

22 C. Crombez, Legislative Procedures in the European Community, „British Journal of Political Science" 1996, vol. 26, nr 2, s. 199-228; idem, The Co-decision Procedure in the European Union, „Legislative Studies Quarterly” 1997, vol. 22, nr 1, s. 97-119; K. Dowding, Institutionalist Research on the European Union, „European Union Politics” 2000, vol. 1, nr 1, s. 124-144; B. Steunenberg, Decision Making under Different Institutional Arrangements: Legislation by the European-Community, ,Journal of Institutional and Theoretical Economics” 1994, vol. 150, nr 4, s. 642-669; G. Tsebelis, The Power of the European Parliament as a Conditional Agenda-Setter, „American Political Science Review" 1994, vol. 88, s. 128-142; G. Tsebelis, G. Garrett, Legislative Politics in the European Union, „European Union Politics” 2000, vol. 1, nr 1, s. 9-36; C. Crombez, B. Steunenberg, R. Corbett, Understanding the EU Legislative Process: Political Scientists' and Practitioners' Perspectives, „European Union Politics” 2000, vol. 1, nr 3, s. 363-381; G. Garrett, G. Tsebelis, R. Corbett, The EU Legislative Proces. Academics vs. Practitioners - Round 2, „European Union Politics” 2001, vol. 2, nr 3, s. 353-366.

${ }^{23}$ M. Pollack, Delegation, Agency, and Agenda Setting in the European Community, „International Organization" 1997, vol. 51, nr 1, s. 121.

24 D. Varela, Just a Lobbyist? The European Parliament and the Consultation Procedure, „European Union Politics" 2009, vol. 10, nr 1, s. 7-34.

25 A. Laruelle, The EU Decision-Making Procedures: Some Insight from Non Co-operative Game Theory, w: Institutional Challenges in the European Union, red. A. van Deemen, M. Widgrén, M. Hosli, London 2002, s. 90; C. Crombez, Legislative Procedures..., s. 205; J. Jupille, Procedural Politics: Issues, In? uence and Institutional Choice in the European Union, Cambridge 2004, s. 48; S. Napel, M. Widgrén, Strategic versus non-strategic voting power in the EU Council of Ministers: the consultation procedure, „Social Choice and Welfare” 2011, vol. 37, s. 5; C. Crombez, The Co-decision procedure..., s. 112; P. Moser, A Theory of the Conditional Influence of the European Parliament in the Cooperation Procedure, „Public Choice” 1997, vol. 91, nr 3-4, s. 345; R. Scully, The European Parliament and the Co-decision Procedure: A Reassessment, „Journal of Legislative Studies" 1997, vol. 3, nr 3, s. 60.

26 J. Ruggie, Constructing the World Polity: Essays on International Institutionalization, New York 1998, s. 33; idem, What Makes the World Hang Together? Neo-utilitarism and the Social Con- 
definiuje je szeroko jako normy sformalizowane i niesformalizowane, cechujące się autonomicznym charakterem ${ }^{27}$, które nie są wyłącznie, jak twierdzi racjonalizm, hamulcem działań podmiotów (norm as constraint), lecz przede wszystkim odgrywają rolę konstruującą (norm as construct) ${ }^{28}$. W takim środowisku funkcjonują jednostki ludzkie, które są ujmowane jako refleksyjne istoty społeczne (homo sociologicus) wyposażone w preferencje, idee czy światopoglądy, które są społecznie konstruowane przez różne konteksty normatywne ${ }^{29}$. Postępują one według logiki stosowności (logic of appropriateness), czyli podejmują działania według norm i tożsamości, które są postrzegane za stosowne $\mathrm{w}$ danej sytuacji ${ }^{30}$. W celu badania przedstawionej rzeczywistości konstruktywizm przyjmuje zarówno metodologię pozytywistycznąjak i postpozytywistyczną; mieszając te dwie perspektywy, próbuje pogodzić obiektywizm z subiektywizmem, w szczególności poprzez szerokie zastosowanie metod jakościowych ${ }^{31}$.

W świetle powyższych założeń, konstruktywizm kwestionuje racjonalistyczną tezę o słabej pozycji Parlamentu w konsultacji. Stawia jej co najmniej dwa zarzuty. Po pierwsze, neguje unitarne i izolacyjne spojrzenie na system instytucjonalny Unii. Konstruktywizm podnosi, iż Rada, Parlament i Komisją są uwikłane w szeroką strukturę normatywną, którą można scharakteryzować z perspektywy przedmiotowej i podmiotowej. Z pierwszego punktu widzenia, choć akty prawne tworzące unijne acquis communautaire są przyjmowane $\mathrm{w}$ ramach różnych procedur formalnych, to w praktyce są ze sobą współzależne. Cechują się bowiem często powiązaną treścią jednoczesnym czasem rozpatrywania czy podobieństwem norm kierujących procesem decyzyjnym. Przykładowo, projekt przyjmowany w ramach konsultacji i dotyczący dopłat dla rolników może być sprzężony z inną propozycją związaną z pomocą dla obszarów wiejskich, która jest w tym samym momencie rozpatrywana $\mathrm{w}$ zwykłej procedurze ustawodawczej. Natomiast z podmiotowego punktu widzenia, współzależność występuje również między głównymi ustawodawcami unijnymi, to jest Radą i Parlamentem. Obie instytucje nie mogą się unikać w toku procesu legislacyjnego, ponieważ decyzja jednej z nich wpływa na działania drugiej. Takie warunki generują potrzebę współpra-

struction Challenge, „International Organization” 1998, vol. 52, nr 4, s. 881; P. Bourdieu, Le sens pratique, Paris 1980, s. 87; M. Barnett, Konstruktywizm społeczny, w: Globalizacja polityki światowej. Wprowadzenie do stosunków międzynarodowych, red. J. Baylis, S. Smith, Kraków 2008, s. 315.

27 P. DiMaggio, W. Powell, The New institutionalism in organizational analysis, Chicago 1991; M. Finnemore, National Interests in International Society, New York 1996, rozdz. 3, 4; M. Pollack, International Relations Theory..., s. 237.

28 N. Tannenwald, W. Wohlforth, The Role of Ideas and The Cold War, ,Journal of Cold War Studies" 2005, vol. 7, nr 2, s. 3-12; A. Klotz, Norms in International Relations. The Struggle against Apartheid, Ithaca 1995, s. 17-27; J. Ruggie, Constructing the World Polity..., s. 22-25; A. Wendt, Social Theory of International Politics, Cambridge 1999, s. 165-166; M. Finnemore, op. cit., s. 1-7 i 128-129; J. Checkel, Social construction and integration, „Journal of European Public Policy” 1999, vol. 6, nr 4, s. 547.

29 E. Adler, Seizing the middle ground: constructivism in world politics, ,European Journal of International Relations” 1997, vol. 3, nr 3, s. 324; J. Ruggie, Constructing the World Polity..., s. 35-36.

30 J. March, J. Olsen, The Institutional Dynamics of International Political Orders, „International Organization" 1998, vol. 52, nr 4, s. 952-954; idem, Rediscovering institutions: The organizational basis of politics, New York 1989, s. 160-162; T. Risse, ,,Let's Argue!”: Communicative Action in World Politics, „International Organization” 2000, vol. 54, nr 1, s. 7-11.

31 M. Barnett, op. cit., s. 318-320; T. Rockmore, On Constructivist Epistemology, Oxford 2005. 
cy przejawiającą się przede wszystkim w znoszeniu izolacji i zwiększeniu częstotliwości spotkan ${ }^{32}$.

Drugi zarzut wobec racjonalistycznej tezy dotyczy jej oparcia wyłącznie na sformalizowanych normach traktatowych. Przedstawiona powyżej struktura normatywna jest niezmiernie skomplikowana i pełna luk, o czym świadczy istotny wpływ interpretacyjny orzecznictwa Trybunału Sprawiedliwości ${ }^{33}$, liczne porozumienia międzyinstytucjonalne ${ }^{34}$ czy obecność takich mechanizmów decyzyjnych jak koncertacja ${ }^{35}$. Podmioty decyzyjne nie są w stanie funkcjonować w takim środowisku wyłącznie na bazie reguł traktatowych, potrzebują wypracowania nieformalnych norm pozwalających przezwyciężyć ten chaos. Te praktyki mogą być z jednej strony rezultatem kontaktów międzyinstytucjonalnych, z drugiej jednak wynikać, zgodnie z założeniem o autonomicznej roli struktur społecznych, z samej konstrukcji środowiska instytucjonalnego, które samoistnie generuje narzędzia decyzyjne mogące być wykorzystane w postępowaniu legislacyjnym przez instytucje w celu zwiększenia własnej pozycji. Dlatego konstruktywizm postuluje, aby spojrzeć na konsultację właśnie z punktu widzenia norm nieformalnych, gdyż ukryte pod powierzchnią reguł traktatowych mogą one je znacznie deformować lub reinterpretować w codziennej praktyce.

Jeśli zatem spojrzeć na konsultację z perspektywy zdeformalizowanego i współzależnego środowiska normatywnego, to kompletnie zmienia się jej obraz. Parlament uzyskuje $\mathrm{w}$ tej procedurze multum możliwości przeforsowania swojego stanowiska wyrażonego w opinii, wystarczy, że tak skomplikuje i uzależni od spełnienia określonych, surowych wymogów podjęcie decyzji przez Radę, że znajdzie się ona w normatywnej sytuacji patowej. Unijne środowisko instytucjonalne dostarcza szeregu struktur umożliwiających osiągnięcie takiego stanu, posłowie muszą jedynie je połączyć w nieformalne instrumenty oddziaływania. Można wyróżnić co najmniej dwa takie narzędzia.

Pierwszym z nich jest metoda pakietowa (issue-linkage, logrolling $)^{36}$. Skoro przyjmowane w Unii akty prawne wielokrotnie charakteryzują się podobną treścią i czasem rozpatrywania, a różnią się wagą dla obu instytucji, to nic nie stoi na przeszkodzie, aby Rada i Parlament handlowały między sobą poparciem dla określonych regulacji czy zawartych w nich rozwiązań (np. poprawek). Przykładowo wyglądałoby to tak, że Rada uzależniałaby swoją akceptację dla propozycji A, która jest ważna dla Parlamentu, w zamian za aprobatę ze strony posłów projektu B, istotnego dla Rady, przy czym oba projekty mogłyby być rozpatrywane w różnych procedurach legislacyjnych. Metoda

32 R. Axelrod, The Evolution of Cooperation, New York 1984, s. 10.

33 A. Stone Sweet, The Judicial Construction of Europe, New York 2004.

34 J. Monar, Interinstitutional Agreements: The Phenomenon and its new dynamics after Maastricht, „Common Market Law Review” 1994, vol. 31, nr 4, s. 693-719; W. Hummer, From 'Interinstitutional Agreements' to 'Interinstitutional Agencies/Of?ces'?, „European Law Journal” 2007, vol. 13 , nr 1 , s. $47-74$.

35 R. Corbett, F. Jacobs, M. Shackleton, op. cit., s. 181-183; M Alfé, When the Linkage of Issues is a Weapon: The EP and the New Financial Regulation, „EIPASCOPE” 2007, nr 2, s. 24.

36 C. Crombez, Spatial models of logrolling in the European Union, „European Journal of Political Economy" 2000, vol. 16, nr 4, s. 707-737; T. Stratmann, Logrolling, w: Perspectives on Public Choice, red. D. Mueller, Cambridge 1997, s. 322-341. 
pakietowa jest przede wszystkim przedmiotem badań racjonalistów w Radzie ${ }^{37}$ i Kongresie Stanów Zjednoczonych ${ }^{38}$, konstruktywizm uzupełnia ją jednak o trzy elementy. Po pierwsze, zgodnie z logiką stosowności, próbuje wyznaczyć warunki środowiska instytucjonalnego, w jakich metoda pakietowa nie tylko staje się formalnie prawdopodobna, ale i jest postrzegana jako odpowiednia przez uczestników procesu decyzyjnego. Dochodzi do wniosku, że jest możliwa w unijnym środowisku międzyinstytucjonalnym, dlatego, po drugie, rozszerza jej stosowanie poza obręb Rady, a więc na cały proces legislacyjny. Po trzecie, traktuje porozumienia pakietowe jako instrumenty nieformalne, nie tylko wpływające na wynik negocjacji, ale także mogące deformować reguły procedur legislacyjnych wyznaczone przez Traktaty.

Strategia pakietowa może znacznie wzmacniać pozycję Parlamentu w konsultacji. Ma to miejsce w szczególności, jeśli połączy on rozpatrywane w tej procedurze projekty $\mathrm{z}$ propozycjami równocześnie uchwalanymi w ramach innych formuł legislacyjnych, zwłaszcza w zwykłej procedurze ustawodawczej, w której ma status prawie równoważny Radzie. Parlament może odmówić współpracy z Radą w tej ostatniej procedurze, jeśli ta nie zaakceptuje jego poprawek w konsultacji. Ma także możliwość przehandlowania swojego poparcia dla projektu w pierwszej procedurze na rzecz ustępstw w drugiej. Wreszcie, w skrajnych przypadkach jest w stanie storpedować proces legislacyjny w obu, łącząc kilka propozycji w formie jednego pakietu. Te trzy nieformalne strategie pozwalają zniwelować do zera formalne różnice między formułami legislacyjnymi, przez co Parlament uzyskuje identyczną pozycję w konsultacji jak i zwykłej procedurze ustawodawczej - sytuacja zdumiewająca z perspektywy Traktatów. Postawiona w patowej sytuacji Rada jest zmuszona do ustępstw na rzecz Parlamentu, żeby móc odblokować kluczowe dla jej członków projekty. Ich brak może bowiem generować dodatkowe koszty i problemy. Powyższe rozważania prowadzą zatem do następującej hipotezy:

\section{H1. Strategie pakietowe zwiększaja pozycję Parlamentu w konsultacji.}

Drugi instrument wynika z faktu, iż konsultacja, jako procedura nieformalna, jest pełna luk prawnych, spośród których kluczowe znaczenie posiada brak określenia w Traktatach terminu, w jakim Parlament powinien dostarczyć Radzie swoją opinię $e^{39}$. Pojawiło się zatem pytanie, czy Rada może samodzielnie wyznaczyć taki czas, czy też Parlament ma prawo permanentnie blokować propozycję legislacyjną, co przypominałoby instytucję weta kieszonkowego (pocket veto) spotykaną w Stanach Zjednoczonych ${ }^{40}$.

37 A. Moravcsik, Preferences and Power in the European Community: A Liberal Intergovernmentalism Approach, „Journal of Common Market Studies” 1993, vol. 31, nr 4, s. 504-507; T. Selck, Explaining the Absence of Inertia in European Union Legislative Decision-Making, „Journal of Common Market Studies" 2005, vol. 43, nr 5, s. 1055-1070.

38 T. Stratmann, The Effects of Logrolling on Congressional Voting, „American Economic Review” 1992, vol. 82, nr 5, s. 1162-1176; idem, Logrolling in the US Congress, „Economic Inquiry” 1995, vol. 23, s. 441-456.

${ }^{39}$ R. Corbett, F. Jacobs, M. Shackleton, op. cit., s. 176. Natomiast takie uprawnienie Rada uzyskała w procedurze konsultowania projektu z Komitetem Regionów i Komitetem Ekonomiczno-Społecznym.

${ }^{40}$ W. Zakrzewski, „Pocket veto” prezydenta Stanów Zjednoczonych, „Państwo i Prawo” 1986, nr 1 , s. $72-82$. 
Rezultatem tej wątpliwości były dwa orzeczenia Trybunału Sprawiedliwości w sprawach Roquette Frères przeciwko Radzie Wspólnot Europejskich ${ }^{41}$ oraz Maizena GmbH przeciwko Radzie Wspólnot Europejskich ${ }^{42}$, zbiorczo nazywanych werdyktem w kwestii izoglukozy (Isoglucose ruling) ${ }^{43}$. W sentencji orzeczono, iż Rada nie może przyjąć aktu prawnego przed otrzymaniem opinii Parlamentu i nie może mu wyznaczyć w tej kwestii żadnych terminów. Trybunał oparł się tutaj na wykładni zasady równowagi instytucjonalnej zakładającej odgrywanie przez Parlament rzeczywistej, nie zaś pobocznej roli w procesie legislacyjnym oraz ,fundamentalnej zasady demokratycznej stanowiącej, iż ludzie powinni partycypować w sprawowaniu władzy za pośrednictwem zgromadzenia przedstawicielskiego" ${ }^{4}$. W ich świetle uchwalenie aktu prawnego bez opinii Parlamentu naruszałoby balans władzy wewnątrz Wspólnot; konsultacja jest bowiem procedura, która daje mu najsłabszą pozycję formalną a więc takie działanie byłoby pogłębieniem tej niekorzystnej sytuacji. Ponadto, prowadziłoby do ograniczenia wpływu reprezentowanych przez Parlament obywateli UE na kształt legislacji. Trybunał orzekł również, że „nie można przyjąć stanowiska, iż postulat [konsultacji - przyp. ASK] jest spełniony wyłącznie poprzez zwykłe zapytanie Rady o opinię", musi ona użyć wszystkich możliwych środków wynikających z Regulaminu PE i Traktatów, aby ją uzyskaćc ${ }^{45}$. Takie stanowisko zostało potwierdzone w wielu kolejnych orzeczeniach $^{46}$.

Powyższe orzecznictwo wyposażało Parlament w silne, nieformalne narzędzie proceduralne, w literaturze określone mianem prawem opóźniania (power of delay) ${ }^{47}$. Dla wielu badaczy oznaczało ono, że może on bezterminowo wstrzymywać przesłanie projektu Radzie, tym samym uniemożliwiać jej podjęcia finalnej decyzji legislacyjnej (indefinite power of delay) $^{48}$. Nie był to jednak pogląd słuszny. Trybunał określił, w szczególności w orzeczeniu w sprawie General Tariff Preferences z 1995 r. ${ }^{49}$, ograniczenia prawa opóźniania, stwierdzając, że Parlament nie może z niego korzystać w sposób

${ }^{41}$ Judgment of the Court of 29 October 1980 - SA Roquette Frères v Council of the European Communities, Case C-138/79, „European Court Reports” 1980, s. 03333.

42 Judgment of the Court of 29 October 1980 - Maizena GmbH v Council of the European Communities, Case C-139/79, „European Court Reports” 1980, s. 03393.

43 Nazwa wywodzi się stąd, że Trybunał rozpatrywał dwie sprawy jednego dnia, to jest 29 października $1980 \mathrm{r}$. oraz że dotyczyły one tego samego problemu - izoglukozy.

44 Judgment of the Court of 29 October 1980 - SA Roquette Frères v Council of the European Communities, Case C-138/79, „European Court Reports” 1980, s. 03333, par 33.

45 Ibidem, s. 03333, par. 34, 36 i 37.

46 Judgment of the Court of 16 July 1992 - European Parliament v Council of the European Communities (Cabotage II), Case C-65/90 „European Court Reports” 1992, s. I-4593, par. 17; Judgment of the Court of 10 May 1995. - European Parliament v Council of the European Union, Case C-417/93, „European Court Reports” 1995, s. I-01185, par. 9; Judgment of the Court of 10 June 1997. - European Parliament $v$ Council of the European Union, Case C-392/95, „European Court Reports” 1997, s. I-03213, par. 14.

47 R. Kardasheva, The Power to Delay: The European Parliament's In? uence in the Consultation Procedure, „Journal of Common Market Studies” 2009, vol. 47, nr 2, s. 385-409.

48 R. Scully, Policy In? uence and Participation in the European Parliament, ,Legislative Studies Quarterly" 1997, vol. 22, nr 2, s. 235.

49 Judgment of the Court of 30 March 1995 - European Parliament v Council of the European Union, Case C-65/93, „European Court Reports” 1995, s. I-00643. 
naruszający zasady szczerej współpracy międzyinstytucjonalnej, ustanowionej przez orzecznictwo w relacjach między państwami członkowskimi a instytucjami UE ${ }^{50}$. Jednocześnie postanowił, że takie nadużycie uprawnia Radę do przyjęcia aktu prawnego bez opinii, co spotkało się z poważną krytyką doktryny ${ }^{51}$ i rzecznika generalnego ${ }^{52}$. Na stan obecny jest to jednak jedyne orzeczenie ograniczające możliwość opóźniania projektu przez Parlament.

W świetle Regulaminu PE, Parlament może stosować prawo opóźnienia na dwa sposoby. Pierwszy ma miejsce, gdy projekt Komisji nie uzyska większości oddanych głosów lub jeżeli zostanie przyjęty wniosek komisji przedmiotowo właściwej lub czterdziestu posłów o jego odrzucenie. W takiej sytuacji Przewodniczący Parlamentu, zanim przejdzie do głosowania nad rezolucją ustawodawczą zwraca się do Komisji o wycofanie propozycji ${ }^{53}$. Jeśli się na to nie zgodzi, Parlament ponownie odsyła sprawę właściwej komisji do dalszych prac, stosując prawo opóźnienia, chyba że na wniosek przewodniczącego lub sprawozdawcy komisji przedmiotowo właściwej, grupy politycznej lub co najmniej 40 posłów, deputowani postanowią o przeprowadzeniu głosowania nad rezolucją ${ }^{54}$. W przypadku odesłania komisja ponownie sporządza sprawozdanie w wyznaczonym przez Parlament terminie (tzw. nieformalne drugie czytanie), który nie może przekroczyć dwóch miesięcy ${ }^{55}$. Jeżeli nie jest w stanie jego dotrzymać, Parlament może wyznaczyć jej nowy termin ${ }^{56}$. Oznacza to, że Parlament ma możliwość długiego zamrożenia projektu.

Drugi sposób opóźniania ma miejsce, gdy Komisja poinformuje posłów, iż nie zamierza przyjąć wszystkich poprawek Parlamentu do projektu konsultacyjnego. W takiej sytuacji sprawozdawca komisji właściwej przedmiotowo lub jej przewodniczący składa na plenum wniosek o przystapieniu do głosowania nad rezolucją ustawodawczą ${ }^{57}$. Posłowie mogą wtedy zadecydować o jego odroczeniu, co automatycznie oznacza odesłanie projektu w celu ponownego rozpatrzenia ${ }^{58}$. W takim przypadku komisja właściwa przedmiotowo ponownie sporządza sprawozdanie w ustalonym przez Parlament terminie, który nie przekracza dwóch miesięcy (tzw. nieformalne drugie czytanie) $^{59}$, przy czym może on jej wyznaczyć nowy termin, gdy poprzedniego nie dotrzyma $^{60}$.

50 Judgment of the Court of 27 September 1988. - Hellenic Republic v Council of the European Communities, Case C-204/86, „European Court Reports” 1988, s. 05323, par. 16; Judgment of the Court of 22 May 1990. - European Parliament $v$ Council of the European Communities (Chernobyl), Case C-70/88, „European Court Reports” 1990, s. I-2041, par. 21.

51 S. Boyron, The Consultation Procedure: Has the Court of Justice Turned against the European Parliament?, „European Law Review” 1996, vol. 21, s. 145-148.

52 Opinion of Mr Advocate General Tesauro delivered on 13 December 1994. - European Parliament $v$ Council of the European Union, Case C-65/93, „European Court Reports” 1995, s. I-00643.

53 Art. 56 ust. 1 Regulaminu PE.

54 Art. 56 ust. 3 zdanie 1 Regulaminu PE.

55 Art. 56 ust. 3 zdanie 2 Regulaminu PE.

56 Art. 56 ust. 4 i art. 175 ust. 5 Regulaminu PE.

57 Art. 57 ust. 2 zdanie 1 Regulaminu PE.

58 Art. 57 ust. 2 zdanie 3 Regulaminu PE.

59 Art. 57 ust. 2 zdanie 4 Regulaminu PE.

${ }^{60}$ Art. 57 ust. 2 zdanie 5 Regulaminu PE. 
Prawo opóźniania zapewnia Parlamentowi nieformalny wpływ na wynik procesu decyzyjnego. Zamrożenie procedury legislacyjnej może stanowić poważne wyzwanie dla państw członkowskich, w szczególności, jeśli projekt dotyczy spraw istotnych oraz wymaga szybkiego przyjęcia ${ }^{61}$. Widmo długiej debaty i sytuacji patowej może generować niecierpliwość członków Rady, którzy są wtedy bardziej skłonni do zapewnienia Parlamentowi ustępstw ${ }^{62}$. Co więcej, rezultatem pasywnej roli Parlamentu jest brak legislacji na czas, co może generować duże koszty dla państw członkowskich. Długookresowe utrzymywanie się takiego stanu powoduje problem z planowaniem i wydatkowaniem unijnych programów pomocowych oraz kreuje luki umożliwiające obywatelom obchodzenie prawa na niekorzyść państwa. Ponadto, opóźnianie umożliwia posłom otwarcie bezpośrednich negocjacji z członkami Rady, albowiem ministrowie, chcąc zapobiec ciagłemu blokowaniu projektu, muszą ich zaprosić do rozmów na temat ewentualnych koncesji. W takich deliberacjach ogromną rolę odgrywają wzajemne relacje, argumentacja i inne struktury społeczne, co zmienia obraz izolacyjnego i de facto jednostronnego podejmowania decyzji w konsultacji na korzyść Parlamentu ${ }^{63}$. Dlatego:

\section{H2. Opóźnianie projektu zwiększa pozycję Parlamentu w konsultacji.}

\section{Badanie empiryczne - rozporządzenie ustanawiające zasady dobrowolnej modulacji płatności bezpośrednich}

W celu weryfikacji zaprezentowanych hipotez zostanie przeprowadzona ich weryfikacja za pomocą jakościowej analizy procedury przyjmowania rozporządzenia ustanawiającego zasady dobrowolnej modulacji płatności bezpośrednich w rolnictwie ${ }^{64}$.

\subsection{Geneza rozporządzenia}

Podstawą do wydania rozporządzenia było porozumienie w sprawie perspektywy finansowej na lata 2007-2013 osiagnnięte w czasie spotkania Rady Europejskiej w Brukseli w dniach 15-16 grudnia $2005 \mathrm{r}^{65}$. Szefowie państw lub rządów postanowili

${ }_{61}$ Tak też twierdzi M. Westlake, A Modern Guide to the European Parliament, London 1994, s. 136.

62 B. Rittberger, Impatient Legislators and New Issue-Dimensions: A Critique of the Garrett - Tsebelis , Standard Version” of Legislative Politics, „Journal of European Public Policy” 2000, vol. 7, $\mathrm{nr} 4$, s. 554-575.

${ }^{63}$ B. Steunenberg, T. Selck, Testing Procedural Models of EU Legislative Decision-Making, w: The European Union Decides: Testing Theories of European Decision Making, red. R. Thomson, F. Stokman, T. König, C. Achen, Cambridge 2006, s. 81; F. Häge, M. Kaeding, Reconsidering the European Parliament's Legislative Influence: Formal vs. Informal Procedures, „Journal of European Integration" 2007, vol. 29, nr 3, s. 357.

${ }_{64}$ Rozporzadzenie Rady (WE) nr 378/2007 z dnia 27 marca 2007 r. ustanawiajace zasady dobrowolnej modulacji płatności bezpośrednich przewidzianych $w$ rozporzadzeniu (WE) $\mathrm{nr}$ 1782/2003 ustanawiajacym wspólne zasady dla systemów wsparcia bezpośredniego w ramach wspólnej polityki rolnej i ustanawiajacym określone systemy wsparcia dla rolników oraz zmieniajace rozporzadzenie (WE) $n r$ 1290/2005, „Dziennik Urzędowy UE” z 5 kwietnia 2007 r., L 95, s. 1-4.

${ }^{65}$ Konkluzje Prezydencji-Bruksela 15-16 grudnia 2005 r., Rada Unii Europejskiej, 15914/1/05 REV 1, 30 stycznia 2006 r., s. 2, pkt 6. 
zmniejszyć środki unijne na rozwój obszarów wiejskich z 88 mld euro do ok. 69 mld euro, a w celu rekompensaty tego ograniczenia ustanowili dyskrecjonalne prawo państw członkowskich do ograniczenia wydatków w ramach rynku i płatności bezpośrednich (I filar Wspólnej Polityki Rolnej) do maksymalnie 20\% i transferu zgromadzonych w ten sposób funduszy na programy rozwoju obszarów wiejskich (II filar WPR) ${ }^{66}$. Porozumienie przewidywało również, że środki przeniesione na rzecz wsparcia II filaru WPR nie będą wchodzić w zakres krajowego współfinansowania. Takie rozwiązania wymagały zmian dostosowujących prawodawstwo unijne, przede wszystkim określenia, w jaki sposób państwa członkowskie mogą stosować dobrowolną modulację, dlatego Rada Europejska wezwała Komisję do przedstawienia stosownego projektu legislacyjnego. Został on zaprezentowany 24 maja $2006 \mathrm{rr}^{67}$, a jego podstawę prawną stanowił art. 37 TWE, zgodnie z którym miał on być rozpatrywany $\mathrm{w}$ ramach procedury konsultacji.

\subsection{Intrainstytucjonalne podejmowanie decyzji}

Propozycja legislacyjna została przesłana Parlamentowi 30 maja 2006 r. Na posiedzeniu 10 lipca ustalono, iż komisją właściwą do jej rozpatrzenia będzie Komisja Rolnictwa i Rozwoju Wsi (AGRI), ponadto, wyznaczono trzy inne komisje do wydania opinii w sprawie projektu - ds. Rozwoju Regionalnego (REGI), ds. Kontroli Budżetowej (CONT) i ds. Budżetu (BUDG) ${ }^{68}$. Sprawozdawcą projektu został wybrany Niemiec Lutz Goepel z frakcji Europejskiej Partii Ludowej - Europejskich Demokratów $\left(\right.$ EPP-ED) ${ }^{69}$.

Projekt Komisji był rozpatrywany dość długo, będąc przedmiotem debat na trzech posiedzeniach AGRI - 12 lipca, 11 września i 3 października 2006 r. Spośród trzech komisji opiniodawczych tylko jedna - BUDG - dostarczyła swoje stanowisko w sprawie rozporządzenia ${ }^{70}$. Zostało ono przyjęte 26 września w sposób jednomyślny (za -18 , przeciw -0 , wstrzymało się -0 posłów) i, zgodnie z uwagami jej sprawozdawcy, Her-

\footnotetext{
${ }^{66}$ Perspektywa finansowa na lata 2007-2013, Rada Unii Europejskiej, 15915/05, 19 grudnia 2005 r., Bruksela, s. 23.

67 Projekt rozporzadzenia Rady ustanawiajacego zasady dobrowolnej modulacji płatności bezpośrednich przewidziane w rozporzadzeniu (WE) nr 1782/2003 ustanawiajacym wspólne zasady dla systemów wsparcia bezpośredniego w ramach wspólnej polityki rolnej i ustanawiajacym określone systemy wsparcia dla rolników oraz zmieniajace rozporzadzenie (WE) nr 1290/2005, Komisja Wspólnot Europejskich, KOM (2006) 241 wersja ostateczna, 24 maja 2006 r. Bruksela.

68 Zgodnie z art. 49 ust. 1 Regulaminu PE: „W przypadku gdy komisja, której jako pierwszej powierzono rozpatrzenie sprawy, pragnie zasięgnąć opinii innej komisji lub jeżeli opinię w sprawie sprawozdania komisji rozpatrującej sprawę jako pierwsza pragnie wydać inna komisja, mogą one zwrócić się do Przewodniczącego Parlamentu o wyznaczenie jednej z nich jako komisji przedmiotowo właściwej, a drugiej jako komisji opiniodawczej”. Komisja przedmiotowo właściwa głosuje nad poprawkami lub wskazówkami komisji opiniodawczej do projektu i tylko ona jest uprawniona do przedstawiania wszystkich ustaleń na posiedzeniu plenarnym (art. 49 ust. 2 i ust. 5 Regulaminu PE).

69 Patrz: art. 45 ust. 2 Regulaminu PE.

70 Zgodnie z art. 49 ust. 3 Regulaminu PE: „Komisja przedmiotowo właściwa wyznacza termin, w jakim musi się wypowiedzieć komisja opiniodawcza, tak aby jej opinia mogła być wzięta pod uwagę przez komisję przedmiotowo właściwą". Po tym terminie uwagi komisji opiniodawczej nie są brane pod uwagę.
} 
berta Böscha, zalecało odrzucenie projektu ${ }^{71}$. Biorąc pod uwagę tę opinię, AGRI zaakceptowała 3 października dużą większością głosów (za - 32, przeciw - 3, wstrzymało się - 0 posłów) sprawozdanie zawierające rezolucję legislacyjną wzywającą Parlament do odrzucenia, a Komisję do wycofania propozycji ${ }^{72}$.

Sprawozdanie opierało swój postulat na kilku argumentach ${ }^{73}$. Po pierwsze, stwierdzało, że projekt zagrażał egzystencji wielu gospodarstw rolnych i doprowadzi do zmniejszenia całości środków przewidzianych dla obszarów wiejskich. Jego przyjęcie miało spowodować obniżenie płatności bezpośrednich nawet o jedną trzecią w porównaniu do 2003 r. (20\% dobrowolnej i 5\% obowiązkowej modulacji oraz 8\% obniżki po przystapieniu Rumunii i Bułgarii), co naruszało rozporządzenie z 2003 r. zamrażające budżet I filaru WPR do $2013 \mathrm{r}^{74}$ Ponadto, wniosek nie przewidywał współfinansowania, co było sprzeczne $z$ uregulowaniami dotyczącymi wszystkich pozostałych funduszy strukturalnych, jak również z wcześniejszymi przepisami dotyczącymi modulacji. Po drugie, sprawozdanie podkreślało, że projekt prowadził do niezgodnej z Traktatami i orzecznictwem Trybunału Sprawiedliwości UE dyskryminacji rolników w poszczególnych państwach członkowskich, gdyż umożliwiał krajowe i pozbawione obiektywnych kryteriów zróżnicowanie metod obliczania wspólnotowego wsparcia dochodów (do 20\%). Po trzecie, wniosek Komisji prowadził do powtórnej nacjonalizacji WPR, ponieważ zapewniał państwom członkowskim jednostronne decydowanie o wysokości dopłat bezpośrednich, jak również o podziale uzyskanych w ten sposób środków wspólnotowych. Po czwarte, sprawozdanie podkreślało, iż projekt lekceważył prawo Parlamentu Europejskiego do współdecydowania. W ramach dobrowolnej modulacji państwa członkowskie mogłyby jednostronnie i bez udziału Parlamentu zwiększyć wydatki nieobowiązkowe o kilka miliardów euro w porównaniu do ram finansowych, co naruszałoby ustalenia Porozumienia międzyinstytucjonalnego w sprawie dyscypliny budżetowej i należytego zarządzania finansami (dalej PM) ${ }^{75}$. Ponadto, wprowadzenie powyższego mechanizmu odbywałoby się przed przeprowadzeniem badania kontrol-

71 Opinia Komisji Budżetowej w sprawie wniosku dotyczqcego rozporzq̨dzenia Rady ustanawiajacego zasady dobrowolnej modulacji płatności bezpośrednich przewidziane $w$ rozporzqdzeniu (WE) nr 1782/2003 ustanawiajacym wspólne zasady dla systemów wsparcia bezpośredniego w ramach wspólnej polityki rolnej i ustanawiajacym określone systemy wsparcia dla rolników oraz zmieniajacego rozporzadzenie (WE) nr 1290/2005, PE 378.594v03-00.

${ }_{72}$ Sprawozdanie w sprawie wniosku dotyczqcego rozporzadzenia Rady ustanawiajacego zasady dobrowolnej modulacji płatności bezpośrednich przewidziane w rozporzqdzeniu (WE) nr 1782/2003 ustanawiajacym wspólne zasady dla systemów wsparcia bezpośredniego w ramach wspólnej polityki rolnej i ustanawiajacym określone systemy wsparcia dla rolników oraz zmieniajacego rozporzqdzenie (WE) nr 1290/2005, A6-0315/2006, PE 376.612v03-00.

73 Patrz: Uzasadnienie, w: Ibidem.

74 Rozporzadzenie Rady (WE) nr 1782/2003 z dnia 29 września 2003 r. ustanawiajqce wspólne zasady dla systemów wsparcia bezpośredniego w ramach wspólnej polityki rolnej $i$ ustanawiajace określone systemy wsparcia dla rolników oraz zmieniajace rozporzqdzenia (EWG) $n r$ 2019/93, (WE) $n r$ 1452/2001, (WE) $n r$ 1453/2001, (WE) $n r$ 1454/2001, (WE) $n r$ 1868/94, (WE) $n r$ 1251/1999, (WE) $n r$ 1254/1999, (WE) $n r$ 1673/2000, (EWG) $n r$ 2358/71 i (WE) $n r$ 2529/2001, „Dziennik Urzędowy UE” z 21 października 2003 r., L 270, s. 1-69.

75 Porozumienie międzyinstytucjonalne pomiędzy Parlamentem Europejskim, Radq i Komisja w sprawie dyscypliny budżetowej i należytego zarzqdzania finansami, „Dziennik Urzędowy UE” z 14 czerwca 2006 r., C 139, s. 1-17. 
nego budżetu, przewidzianego na lata 2008-2009, mającego być podstawą do przygotowania propozycji na okres finansowania po 2013 r. Zgodnie z PM, takie badania kontrolne i wszystkie przygotowane na jego podstawie propozycje powinny być opracowywane w ścisłej współpracy z Parlamentem ${ }^{76}$, co w analizowanym kontekście nie miało miejsca. Wreszcie, projekt nie zawierał oceny skutków regulacji skonsultowanych z zainteresowanymi środowiskami, do czego Komisja zobowiązała się wobec Parlamentu w Porozumieniu międzyinstytucjonalnym w sprawie lepszego stanowienia prawa $^{77}$. Sprawozdanie konkludowało: ,oczekuje się, iż Parlament w procedurze zgodnej z art. 37 TWE zatwierdzi przygotowany potajemnie przez Radę wniosek o ogromnym znaczeniu" ${ }^{\prime 78}$.

Parlament pozytywnie odniósł się do powyższych zastrzeżeń. W czasie debaty przeprowadzonej 13 listopada prawie wszystkie frakcje wyraziły sprzeciw wobec projektu Komisji. Jej przedstawicielka, komisarz ds. rolnictwa i rozwoju wsi Mariann Fischer Boel, oznajmiła jednak, że go nie wycofa, ponieważ jest zgodny z postulatami Rady Europejskiej wynikającymi z zaproszenia, które Komisja przyjęła i zobowiązała się wykonać ${ }^{79}$. W efekcie, następnego dnia posłowie odrzucili projekt znaczną większością głosów (za - 64, przeciw - 559, wstrzymało się - 16 posłów) ${ }^{80}$. Zgodnie z art. 56 ust. 1 Regulaminu PE, Przewodniczący PE zwrócił się do Komisji z prośbą o jego wycofanie, jednak jej reprezentant, komisarz ds. rynku wewnętrznego i usług Charlie McCreevy, nie zgodził się na taki krok, powtarzając argumentację Fischer Boel ${ }^{81}$. W odpowiedzi Przewodniczący PE odroczył głosowanie nad rezolucją legislacyjną i odesłał projekt z powrotem do AGRI w celu dalszych prac. Zastosował zatem,,prawo opóźnienia” zgodnie z omówionym powyżej pierwszym sposobem.

AGRI oraz sprawozdawca L. Goepel ponownie zajęli się projektem, analizując go na dwóch spotkaniach - 18 grudnia 2006 r. i 24 stycznia 2007 r. W czasie obrad ustalono, że problemy, które doprowadziły do odrzucenia wniosku na posiedzeniu plenarnym, nie zostały przez Komisję rozwiązane w sposób satysfakcjonujący. Dlatego AGRI przyjęła znaczną większością głosów (za - 32, przeciw - 3, wstrzymało się - 1 posłów) drugie sprawozdanie wzywające Parlament do odrzucenia, a Komisję do wycofania projektu ${ }^{82}$.

${ }^{76}$ Deklaracja $n r 3$ w sprawie przegladu ram finansowych, w: Ibidem, s. 15.

77 Porozumienie międzyinstytucjonalne w sprawie lepszego stanowienia prawa z dnia 16 grudnia 2003 r., „Dziennik Urzędowy” z 31 grudnia 2003 r., C 321, s. 1-5.

78 Uzasadnienie, w: Sprawozdanie w sprawie wniosku dotyczqcego rozporzadzenia Rady ustanawiajacego zasady dobrowolnej modulacji płatności...

79 Wsparcie rozwoju obszarów wiejskich przez EFRROW-Dobrowolna modulacja dopłat bezpośrednich w ramach WPR (debata), CRE 13/11/2006 - 20, 13 listopada 2006 r., Strasburg.

${ }_{80}$ Załacznik II. Wyniki głosowań imiennych, w: Parlament Europejski. Protokót z posiedzenia 14 listopada 2006 r., „Dziennik Urzędowy UE” z 21 grudnia 2006 r., C 314 E, s. 56.

${ }_{81}$ Dobrowolna modulacja dopłat bezpośrednich w ramach WPR (głosowanie), CRE 14/11/2006-9.17, 14 listopada 2006 r., Strasburg.

${ }^{82}$ Drugie sprawozdanie w sprawie wniosku dotyczqcego rozporzadzenia Rady ustanawiajacego zasady dobrowolnej modulacji płatności bezpośrednich przewidzianych $w$ rozporzadzeniu (WE) nr 1782/2003 ustanawiajacym wspólne zasady dla systemów wsparcia bezpośredniego w ramach wspólnej polityki rolnej $i$ ustanawiajacym określone systemy wsparcia dla rolników oraz zmieniajacego rozporzqdzenie (WE) nr 1290/2005, A6-0009/2007, PE 382.346v02-00. 
Parlament po raz kolejny podzielił stanowisko AGRI i w trakcie drugiego nieformalnego czytania 14 lutego 2007 r. odrzucił propozycję znaczną większością głosów (za projektem -89 , przeciw -584 , wstrzymało się -19 posłów ${ }^{83}$ ). Przewodniczący PE po raz kolejny zapytał reprezentanta Komisji, komisarza ds. sprawiedliwości, wolności i bezpieczeństwa Franco Frattiniego, czy wycofa projekt, jednak ten stwierdził, że tego nie uczyni. Parlament był zatem zdecydowany ponownie odesłać propozycję do AGRI, jednak pod wpływem jej przewodniczącego, Neila Parisha oraz obiekcji Służb Prawnych Parlamentu ${ }^{84}$, zaniechał tego i przyjął rezolucję legislacyjną ${ }^{85}$ potwierdzającą odrzucenie projektu (za rezolucja - 572, przeciw - 65, wstrzymało się - 16 posłów) ${ }^{86}$. Oznaczało to, że posłowie zakończyli opóźnianie propozycji i, przyjmując opinię, umożliwili Radzie podjęcie ostatecznej decyzji. Uczynili to, ponieważ w międzyczasie zastosowali nowy instrument, który jeszcze bardziej zablokował i skomplikował ministrom proces decyzyjny.

\subsection{Interinstytucjonalne podejmowanie decyzji}

Kiedy 3 października 2006 r. AGRI przyjęła sprawozdanie odrzucające projekt, posłowie przeprowadzili kuluarowe rozmowy z pracownikami Komisji, z których wynikało, że nie zostanie on wycofany. Sygnały przychodzące z Rady również były niepomyślne - opóźnianie nie zrobiło na ministrach wielkiego wrażenia. Dalsze blokowanie propozycji nie przyniosłoby zatem rozwiązania patowej sytuacji, wręcz przeciwnie, zrzucałoby na Parlament odium winowajcy tego stanu rzeczy ${ }^{87}$ oraz groziło zarzutem braku szczerej współpracy, tudzież sprawą przed Trybunałem. W takich warunkach posłowie postanowili połączyć kwestię dobrowolnej modulacji z negocjacjami nad budżetem Unii na 2007 r., czyli zastosować metodę pakietową. Na swoim posiedzeniu z 26 października 2006 r. Parlament przyjął w pierwszym czytaniu sprawozdanie Brytyjczyka Jamesa Ellesa (EPP-ED) z BUDG przewidujące zablokowanie w Sekcji III tego budżetu $20 \%$ wydatków na programy rozwoju obszarów wiejskich (m.in. Europejski Fundusz Rolny na rzecz Rozwoju Obszarów Wiejskich) i przeniesienie ich do rezerwy ${ }^{88}$. De-

83 Załacznik I. Wyniki głosowania, w: Parlament Europejski. Protokót z posiedzenia 14 lutego 2007 r., „Dziennik Urzędowy UE” z 29 listopada 2007 r., C 287 E, s. 212.

${ }^{84}$ Dobrowolna modulacja dopłat bezpośrednich w ramach WPR (głosowanie), CRE 14/02/2007-5.5, 14 lutego 2007 r., Strasburg.

${ }_{85}$ Rezolucja legislacyjna Parlamentu Europejskiego w sprawie wniosku dotyczacego rozporzadzenia Rady ustanawiającego zasady dobrowolnej modulacji płatności bezpośrednich przewidzianych $w$ rozporzadzeniu (WE) nr 1782/2003 ustanawiajacym wspólne zasady dla systemów wsparcia bezpośredniego $w$ ramach wspólnej polityki rolnej $i$ ustanawiajacym określone systemy wsparcia dla rolników oraz zmieniajacego rozporzqdzenie (WE) nr 1290/2005, P6 TA(2007)0036, T6-0036/2007, 14 lutego 2007 r., Strasburg.

${ }^{86}$ Załacznik I. Wyniki glosowania..., op. cit., s. 212.

$87 \mathrm{Z}$ omawianych w niniejszym artykule dokumentów i protokołów dotyczących procedury przyjęcia rozporządzenia wynika, że Komisja i Rada nie kryli swojego zdziwienia i frustracji postawą Parlamentu.

${ }^{88}$ Rezolucja Parlamentu Europejskiego w sprawie projektu budżetu ogólnego Unii Europejskiej na rok budzetowy 2007, Sekcja III - Komisja i pismo w sprawie poprawek nr 1/2007 (SEC(2006)0762) 
cyzję tę podtrzymał w dalszych negocjacjach, w konsekwencji ustanowiona przez posłów rezerwa znalazła się w budżecie przyjętym ostatecznie dnia 14 grudnia 2006 r. ${ }^{89}$ Jednocześnie Parlament poinformował Radę, że powyższe ograniczenie zostanie wycofane, jeśli zaakceptuje ona jego opinię dotyczącą dobrowolnej modulacji wyrażoną w konsultacji ${ }^{90}$.

Taki krok spotkał się wreszcie z odpowiedzią Rady. W czasie posiedzenia Specjalnego Komitetu ds. Rolnictwa ${ }^{91} 12$ lutego 2007 r. podjęto decyzję o zaproszeniu przedstawicieli Parlamentu na nieformalne spotkania zwane trilogami ${ }^{92}$, w czasie których miano wypracować porozumienie. Jednocześnie delegacje państw członkowskich zaaprobowały zarys kompromisu przedstawionego przez prezydencję, który miał być mandatem Rady w czasie tych negocjacji ${ }^{93}$. Trilogi odbywały się trzykrotnie -27 lutego, 6 marca oraz 14 marca - i uczestniczyli w nich delegaci prezydencji Rady, sprawozdawca L. Goepel, Jan Mulder z AGRI i Herbert Bösch z BUDG. Ich efektem było porozumienie, w którym Parlament zobowiązał się do zniesienia blokady $20 \%$ środków budżetowych na programy rozwoju obszarów wiejskich pod dwoma warunkami. Po pierwsze, Rada musiała wyrazić zgodę na treść wypracowanego w trilogach projektu rozporządzenia, którego najważniejszymi modyfikacjami było zapewnienie stosowa-

do projektu budżetu ogólnego WE na rok budżetowy 2007, P6_TA(2006)0451, 26 października 2006 r., Strasburg, pkt 23.

${ }^{89}$ Budżet ogólny Unii Europejskiej na rok budżetowy 2007, „Dziennik Urzędowy UE” z 16 marca 2007 r., L 77, s. II-1 i nast.

90 Proposal for a Council Regulation Laying down Rules for Voluntary Modulation of Direct Payments Provided for in Regulation (EC) No 1782/2003 Establishing Common Rules for Direct Support Schemes under the Common Agricultural Policy and Establishing Certain Support Schemes for Farmers, and amending Regulation (EC) No 1290/2005, 7014/07, Council of the European Union: Special Committee on Agriculture, Brussels, 5 March 2007.

91 Specjalny Komitet ds. Rolnictwa (SCA) jest jednym z organów przygotowawczych Rady średniego szczebla, który opracowuje agendę spotkań Rady ds. Rolnictwa i Rybołówstwa. Patrz: Fifty years for the Special Committee on Agriculture, Council of European Union, 13285/1/10 REV 1, Brussels, 9 September 2010, s. 2; F. Hayes-Renshaw, H. Wallace, The Council of Ministers, Basingstoke 2006, s. 95; P. Culley, The Agriculture and Fisheries Council, w: The Council of the European Union, red. M. Westlake, D. Galloway, London 2004, s. 152.

92 Trilogi vel trialogi są to nieformalne spotkania ,za zamkniętymi drzwiami” przedstawicieli Komisji (szefowie określonych Dyrekcji Generalnych), Rady (przewodniczący COREPER i grup roboczych) oraz Parlamentu (wiceprezydenci, przewodniczący komisji, sprawozdawcy, sprawozdawcy-cienie, koordynatorzy grup politycznych) w trakcie procedury prawodawczej, których celem jest jak najszybsze doprowadzenie do porozumienia legislacyjnego. Ich efektem jest zjawisko finalizacji większości aktów prawnych w pierwszym czytaniu (w latach 2009-2010 - 97\%). Patrz: H. Farrell, A. Héritier, Interorganizational Negotiation and Intraorganizational Power in Shared Decision-Making: Early Agreements under Codecision and Their Impact on the European Parliament and Council, „Comparative Political Studies” 2004, vol. 37, nr 10, s. 1197; H. Farrell, A. Héritier, Formal and informal institutions under codecision..., s. 592; A. Héritier, C. Reh, Codecision and its Discontents: Intra-organisational Politics and Institutional Reform in the European Parliament, paper prepared for the EUSA Biannual Meeting, Boston, 3-5 March 2011; A. Rasmussen, Early conclusion in bicameral bargaining: Evidence from the co-decision legislative procedure of the European Union, „European Union Politics" 2011, vol. 12, nr 1, s. 41-64.

93 Wniosek dotyczqcy rozporzqdzenia Rady ustanawiajqcego zasady dobrowolnej modulacji płatności bezpośrednich zgodnie z rozporzadzeniem (WE) 1782/2003 ustanawiajacym wspólne zasady dla systemów wsparcia bezpośredniego w ramach wspólnej polityki rolnej i ustanawiajacym określone systemy wsparcia dla rolników oraz zmieniajacego rozporzadzenie (WE) nr 1290/2005, 6433/07, Rada Unii Europejskiej: Specjalny Komitet ds. Rolnictwa, 15 lutego 2007 r., Bruksela. 
nia dobrowolnej modulacji tylko dla Wielkiej Brytanii i Portugalii oraz nałożenie na Komisję obowiązku przedstawienia Radzie i Parlamentowi w 2008 r. raportu w ramach „przeglądu zdrowotnego" reformy WPR (Health- Check 2008/2009) oceniającego aplikację tego mechanizmu wraz z odpowiednimi propozycjami. Po drugie, w chwili przyjmowania przedmiotowego rozporząazenia Zjednoczone Królestwo Wielkiej Brytanii miało złożyć oświadczenie (włączone do porozumienia), w którym zobowiązywało się, że wielkość zastosowanej w latach 2007-2013 dobrowolnej modulacji wyniesie mniej niż $20 \%$, a $80 \%$ kwoty przychodów z tego tytułu zostanie przeznaczona na środki rozwoju obszarów wiejskich, mające na celu ochronę środowiska i będzie współfinansowana przez to państwo ${ }^{94}$.

\subsection{Finalizacja decyzji}

Realizacja tego porozumienia nastapiła niezmiernie szybko. Już 19 marca 2007 r. na posiedzeniu ministerialnym Rady ds. Rolnictwa i Rybołówstwa przyjęto jednomyślnie polityczne porozumienie (political agreement) ${ }^{95}$, które akceptowało wypracowane w trilogach ustalenia ${ }^{96}$. W efekcie, dwa dni później BUDG zaakceptował wniosek Komisji, aby przenieść $20 \%$ zamrożonych w budżecie środków z rozdziału „rezerwa” do rozdziału „rozwój obszarów wiejskich" ${ }^{\text {97 }}$. Procedura legislacyjna została ostatecznie sfinalizowana 27 marca 2007 r., kiedy Rada ds. Gospodarczych i Finansowych (ECOFIN) przyjęła, przy jednym głosie wstrzymującym się Łotwy ${ }^{98}$, rozporządzenie umożliwiające zastosowanie dobrowolnej modulacji płatności bezpośrednich tylko dwóm, wymienionym powyżej państwom ${ }^{99}$.

94 Wniosek dotyczqcy rozporzqdzenia Rady ustanawiajqcego zasady dobrowolnej modulacji płatności bezpośrednich przewidzianych w rozporzqdzeniu (WE) nr 1782/2003 ustanawiajacym wspólne zasady dla systemów wsparcia bezpośredniego w ramach wspólnej polityki rolnej i ustanawiajacym określone systemy wsparcia dla rolników, oraz zmieniajqce rozporzqdzenie (WE) $n r$ 1290/2005, 7334/07 COR 1 + ADD1, Rada Unii Europejskiej: Prezydencja do Rady, 19 marca 2007 r., Bruksela.

95 Polityczne porozumienia są to ustalenia ministrów w trakcie prac nad projektem mających miejsce na niższych szczeblach Rady. Są zawierane w sytuacji, gdy grupy robocze i COREPER nie są w stanie osiaggnąc kompromisu w zasadniczych, nietechnicznych kwestiach. Patrz: F. Häge, Politicising Council Decision-making: The Effect of European Parliament Empowerment, „West European Politics" 2011, vol. 34, nr 1, s. 33.

96 Przyjęcie rozporzadzenia Rady ustanawiajacego zasady dobrowolnej modulacji płatności bezpośrednich przewidzianych w rozporzadzeniu (WE) nr 1782/2003 ustanawiajacym wspólne zasady dla systemów wsparcia bezpośredniego w ramach wspólnej polityki rolnej i ustanawiajacym określone systemy wsparcia dla rolników oraz zmieniajacego rozporzqdzenie (WE) nr 1290/2005, Rada Unii Europejskiej: Specjalny Komitet ds. Rolnictwa do Rady, 7678/07 + COR 1 + ADD1, 22 marca 2007 r., Bruksela.

${ }_{97}$ Przesunięcie środków nr Dec 6/2007, wydatki nieobowiazkowe, SEC (2007) 157 wersja ostateczna, Komisja Wspólnot Europejskich, Bruksela, 20 lutego 2007 r.

98 Łotwa wstrzymała się od głosu, chcąc zamanifestować swoją krytykę jakiejkolwiek modulacji (dobrowolnej jak i obowiązkowej) oraz wezwać do implementacji działań realizujących strategię lizbońską zmniejszających nierówności między obszarami wiejskimi „starych” i ,nowych” państw członkowskich. Patrz: Oświadczenie delegacji łotewskiej (26/07), w: Miesięczny wykaz aktów Rady - Marzec 2007 r., Rada Unii Europejskiej, 10463/07, 6 czerwca 2007 r., Bruksela, s. 13-14.

99 Ibidem, s. 3; Komunikat prasowy: 2792. posiedzenie Rady ds. Gospodarczych i Finansowych, C/07/50 7245/07 (Presse 50), Rada Unii Europejskiej, Bruksela, 27 marca 2007 r., s. 3. 


\subsection{Podsumowanie kazusu}

Przedstawiony powyżej kazus potwierdza konstruktywistyczne hipotezy - Parlament może posiadać dominującą pozycję w konsultacji. Posiada on w swoim arsenale co najmniej dwa narzędzia - opóźnianie i pakiety - za pomocą których może przeforsować swoje stanowisko w przypadku spraw o szczególnie ważnym dla niego znaczeniu. Badane rozporządzenie pokazuje przede wszystkim, że oba instrumenty stanowią łącznie poważną siłę. Początkowo, Parlament próbował opóźniać projekt, chcąc dać wyraźny sygnał, iż postępowanie Komisji i Rady uderza w założenia unijnego rolnictwa oraz samych rolników. Działanie takie nie przyniosło jednak efektów z dwóch powodów. Po pierwsze, propozycja miała silne ugruntowanie w konkluzjach Rady Europejskiej, a więc instytucji, która ,nadaje Unii impulsy niezbędne do jej rozwoju i określa ogólne kierunki i priorytety polityczne"100. To powodowało niechęć Komisji do jakichkolwiek modyfikacji. Po drugie, członkowie Rady byli zdeterminowani, aby ustanowić dobrowolną modulację, choćby zajęło to wiele miesięcy, nie działała tu zatem presja czasu, tak bardzo ważna przy opóźnianiu. Projekt Komisji pozwalał bowiem znacjonalizować WPR ,tylnymi drzwiami” oraz ograniczyć krajowe wydatki na ten cel - rozwiązania niezmiernie kuszące dla rządów. W tych warunkach Parlament nie mógł opóźniać projektu w nieskończoność, tym bardziej, że narażał się na zarzut braku szczerej współpracy, co w świetle orzeczenia General Tariff Preferences mogło prowadzić do negatywnych konsekwencji. Postanowił więc wytoczyć cięższe działa i, porzucając ten mechanizm, połączył kwestię dobrowolnej modulacji z regulacjami mającymi dla członków Rady kapitalne znaczenie - zamrożeniem środków na programy rozwoju rolnictwa w budżecie na 2007 r. Był to poważny cios dla państw członkowskich, ponieważ nie tylko ograniczał dla nich dofinansowanie, ale także opóźniał implementację krajowych programów pomocowych dla obszarów wiejskich (ich zatwierdzenie ma miejsce na przełomie lutego i marca), tworzył niepewność finansową generującą dodatkowe koszty administracyjne oraz czynił realizację wcześniejszych zobowiązań rządów wobec rolników (np. kredyty) zagrożoną. W efekcie, Rada musiała uwzględnić wątpliwości Parlamentu i zaprosić jego przedstawicieli do trilogu.

Negocjacje pozwoliły posłom bezpośrednio wpłynąć na ostateczny kształt rozporządzenia. Ich postulaty zostały zaakceptowane - do dobrowolnej modulacji zostały uprawnione tylko dwa państwa, a jej słuszność miała być zweryfikowana w 2008 r. Można oczywiście stwierdzić, iż takie rozwiązanie nie było sukcesem, gdyż Parlament był bezwzględnie przeciwny formie tego środka zaproponowanej w projekcie Komisji. Należy jednak pamiętać, iż w świetle założeń konstruktywistycznych podejmowanie decyzji w Unii Europejskiej nie ma charakteru racjonalistycznej gry o sumie zerowej, lecz odbywa się w kooperacyjnym środowisku normatywnym, nakazującym poszukiwanie konsensusu i zakazującym maksymalizacji swoich żądań ${ }^{101}$. Trilog jest mecha-

100 Art. 15 ust. 1 TUE.

101 D. Heisenberg, The institution of 'consensus' in the European Union: Formal versus informal decision-making in the Council, „European Journal of Political Research” 2005, vol. 44, nr 1, s. 65-90; O. Elgstrom, C. Jonsson, Negotiation in the European Union: Bargaining or problem-solving?, „Journal of European Public Policy” 2000, vol. 7, nr 5, s. 684-704; D. Naurin, Most 
nizmem, w którym te normy są szczególnie obecne i istotne ${ }^{102}$, dlatego reprezentanci trzech instytucji poszukiwali takiego rozwiązania, które byłoby satysfakcjonujące dla wszystkich.

Analizowany kazus przynosi jeszcze jeden, ciekawy wniosek. W literaturze funkcjonuje pogląd, iż Parlament ma słaby wpływ na WPR, stanowi ona raczej domenę rządów i Komisji ${ }^{103}$. Niniejsza analiza pokazuje jednak, że instrumenty opóźniająco-pakietowe Parlamentu są skuteczne nawet w tym obszarze. To zjawisko jest pewnym novum, jak bowiem stwierdził po przyjęciu rozporządzenia o dobrowolnej modulacji Jan Mulder: „Po raz pierwszy w historii Parlament doprowadził Radę do takich ustępstw w sektorze rolnictwa. Dotychczas odgrywał on wyłącznie rolę doradczą. Postrzegam to porozumienie jako wielkie zwycięstwo demokracji w Europie" ${ }^{\text {"104 }}$. To potwierdza tylko konstruktywistyczną tezę, że proces decyzyjny w Unii Europejskiej cechuje się normatywną i strukturalną współzależnością, która sama w sobie ma transformacyjny wpływ na preferencje i decyzje aktorów we wszystkich obszarach unijnych.

\section{Konkluzje}

Niniejszy artykuł dowodzi, że choć formalnie Parlament posiada słabą pozycję w procedurze konsultacji, to dysponuje szeregiem nieformalnych instrumentów zapewniających mu znaczny wpływ na kształt projektów przyjmowanych w tej procedurze. Takie narzędzia czerpie ze skomplikowanego, zdeformalizowanego i współzależnego unijnego środowiska normatywnego, w którym funkcjonuje, charakteryzującego się licznymi lukami oraz powiązaniami między projektami i podmiotami. Ma ono transformacyjny wpływ na wybory i preferencje decydentów, przez co umożliwia tworzenie się zjawisk i mechanizmów deformujących formalne reguły traktatowe. Analiza procesu uchwalania rozporządzenia o dobrowolnej modulacji wykazała, iż Parlament może po-

Common When Least Important: Deliberation in the European Council of Ministers, „British Journal of Political Science" 2009, vol. 40, nr 1, s. 31-50; J. Lewis, The Janus face of Brussels: socialization and everyday decision-making in the European Union, „International Organization” 2005, vol. 59, $\mathrm{nr}$ 4, s. 937-971; idem, Is the 'Hard Bargaining' Image of the Council Misleading? The Committee of Permanent Representatives and the Local Elections Directive, „Journal of Common Market Studies” 1998, vol. 36, nr 4, s. 479-504; A. Juncos, K. Pomorska, Playing the Brussels game: Strategic socialisation in the CFSP Council Working Groups, „European Integration Online Papers” 2006, vol. 10, s. $8-9$.

102 J. Lewis, Informal Integration and the Supranational Construction of the Council, ,Journal of European Public Policy" 2003, vol. 10, nr 6, s. 996-1019; idem, How Institutional Environments Facilitate Cooperative Negotiation Styles in EU Decision Making, „Journal of European Public Policy” 2010, vol. 17, nr 5, s. 650-666; D. Naurin, Safe Enough To Argue? Giving Reasons in the Council of the EU, „ARENA Working Paper” 2007, nr 11.

103 P. Culley, op. cit., s. 204; A. Cunha, A. Swinbank, Exploring the Determinants of CAP Reform: A Delphi Survey of Key Decision-Makers, ,Journal of Common Market Studies” 2009, vol. 47, nr 2, s. $247,255$.

104 Voluntary Modulation of CAP Aids Strictly Limited Thanks to the European Parliament, European Parliament Press Service: Agriculture, 21 March 2007, http://www.europarl.europa.eu/sides/getDoc.do?pubRef=-//EP//NONSGML+IM-PRESS+20070321IPR04414+0+DOC+PDF+V0// EN\&language $=\mathrm{NL}$ (dostęp: 4 sierpnia 2011 r.). 
przez co najmniej dwa nieformalne instrumenty - opóźnianie i strategię pakietową - znacznie ograniczać autonomię decyzyjną Rady w konsultacji, doprowadzając nawet do dominacji nad tą instytucją - sytuacji niemożliwej z punktu widzenia postanowień Traktatów. Dlatego choć de iure pozycja Parlamentu w tej procedurze jest ograniczona tylko do wydawania niewiążących opinii, to de facto środowisko normatywne dostarcza mu szeregu instrumentów zapewniających prawie równorzędny status w procesie legislacyjnym.

Nie sposób jednak nie wspomnieć o ograniczeniach powyższego badania. Koncentruje się ono wyłącznie na analizie jednego aktu prawnego, nie pozwala zatem być pewnym wiarygodności konstruktywistycznych wniosków oraz wyprowadzić generalizacji na inne przypadki. Potrzebne jest uzupełnienie o badania ilościowe, które wykażą, czy nieformalne mechanizmy stosowane przez Parlament są statystycznie skuteczne i często stosowane. Ich metoda powinna być oparta na analizie dużej ilości projektów konsultacyjnych pod kątem poziomu oraz warunków akceptacji poprawek Parlamentu. To wyzwanie dla badaczy Unii Europejskiej jest warte podjęcia, gdyż z pewnością rzuci nowe światło na zaniedbaną w literaturze procedurę konsultacji.

\section{Summary}

\section{Formally weak, informally strong. The position of the European Parliament in the consulting procedure, based on the example of the process of passing the resolution establishing the principles for voluntary modulation of direct payments}

Widespread, rationalist thesis states that the position of the European Parliament in the consultation procedure is insignificant. Its limited powers come down to giving opinions for the Commission proposals before the Council can proceed with adopting it. However, it is the Council that decides whether to incorporate or ignore the EP's amendments in the final legislative act. Different view on consultation is presented by social constructivism. It assumes that institutions operate in the complicated normative environment where legislative procedures and proposals are interdependent. This system is full of informal practices and social rules which not only facilitates decision-making but also deforms and reinterprets Treaties provisions. Entangled in this environment, the EP has the possibility to take advantage of it to reinforce its position in consultation. For instance, it can informally block the procedure by linking issues, delaying or creating decision-making stalemates for the Council. Though the EP's de iure powers under consultation are limited, its de facto position might be powerful.

The article examines abovementioned theses by analyzing the passing procedure of the Council Regulation (EC) No 378/2007 of 27 March 2007 laying down rules for voluntary modulation of direct payments, one of the most important consultation act in the European Union's agriculture field. The case-study confirms the constructivist prediction. By using ,power of delay” and issue-linkage strategy, the EP can significantly influence EU legislative outcomes. Not only is it able to block the whole procedure but also to force the Council to accept the substance of its opinion in the final legislative text. Therefore, despite the fact that Treaties give weak competences under consultation to the EP, this institution can acquire dominant position in this procedure. 
